\title{
PREVALENCE OF MAJOR DEPRESSION IN PATIENTS WITH BREAST CANCER
}

\author{
Sionara Melo Figueiredo de Carvalho1,2, Italla Maria Pinheiro Bezerra1, \\ Thiago Holanda Freitas ${ }^{3}$, Ricardo César da Silva Rodrigues ${ }^{1}$, \\ Idelfonso Oliveira Chaves de Carvalho', Aline Quental Brasil' \\ Francisco Telésforo Celestino Júnior ${ }^{2}$, Lucyo Flávio Bezerra Diniz ${ }^{1}$, Alexandra Paz-Cox ${ }^{1}$, \\ Luiz Carlos de Abreu ${ }^{1}$
}

Clinical application: To screen patients with breast cancer without previous depression diagnosis in a proper way, avoiding the classification of subsyndromal depressive symptoms or moderate depressive disorders such as major depression.

DOI: http://dx.doi.org/10.7322/jhgd.96770

\begin{abstract}
:
Introduction: breast cancer is one of the main causes of death among women in Brazil and worldwide. The diagnosis of breast neoplasms usually represents an emotional burden, and it may lead to adjustment reactions and even be the trigger for affective disorders (mainly depression), anxiety or psychosis. The Beck Depression Inventory (BDI) is one of the most used mechanisms for the evaluation of depression in research and in clinics. Depression prevalence in patients with cancer varies from $3 \%$ to $55 \%$ among different studies. Methodological variation, different instruments to assess depression and different cut-off points for diagnosis contribute to the huge discrepancy in current findings. In general, the more specifically depression is defined and evaluated, the lower the rates of prevalence are reported. Many articles fail to demonstrate a statistical significance in the relationship between depression and cancer-specific factors. This suggests that risk factors for depression in those patients are more related to the patient - as contextual variables and premorbid factors of personality - and not to the cancer or its treatment. Objective: to determine the prevalence of major depression in women with breast cancer. Methods: a cross-sectional study was conducted in women with breast cancer. The sample consisted of 51 patients who answered the Beck Depression Inventory (BDI). The presence of depression was considered in cases where the scores were above 20. A questionnaire with additional data about the patients such as age, marital status, ethnicity, education, family income, family history of depression and breast cancer, and cancer-related variables including staging, months since diagnosis, treatment modality, type of surgery, alopecia occurring were used. Descriptive analysis and test of association (chi-square) were conducted. Results: the prevalence of major depression was $5.9 \%$, similar to that observed in community samples. Subsyndromal depressive symptoms had a score of $21.6 \%$ (BDI scores from 16 to 20). Chi-square test was conducted and showed no statistically significant relationship between the classification of BDI and the variables tested (characteristics related to patient and cancer-specific). This indicates that the isolated context of the variables does not influence the event of depression. Conclusion: the prevalence of major depression in women with breast neoplasms was $5.9 \%$.
\end{abstract}

Key words: breast cancer, breast neoplasms, prevalence, cross-sectional studies, major depression, mood disorders.

\section{INTRODUCTION}

Breast cancer is the second most common type of cancer in the world population and more common among women, being one of the leading causes of death among them worldwide. ${ }^{1-3}$. About 520,000 deaths from the disease has been estimated for the year 2012. In Brazil, in 2010, the number of deaths due to this cancer was 12,852 $(12,705 \text { females and } 147 \text { males })^{2}$ and these mortality rates remain high in the country because the disease is still diagnosed in advanced stages. ${ }^{3}$
Cancer places specific demands on individuals, with substantial stressors both at diagnosis and during treatment. ${ }^{4}$ Mammary neoplasms make demands on women's physical and psychological aspects, ${ }^{5}$ and within the analysis of the patients' surgical and adjuvant treatment the impact on their mental health should be emphasized 6 .

Cancer diagnosis is usually an emotional overload which can trigger reactions and emotional adjustment or even be the trigger for affective disorders (especially depression), anxiety or even

\footnotetext{
1 Laboratório de Delineamento de Estudos e Escrita Científica da Faculdade de Medicina do ABC, Santo André-SP, Brazil.

2 Universidade Federal do Cariri, Faculdade de Medicina, Barbalha-CE, Brazil.

3 Universidade de Fortaleza, Fortaleza-CE, Brazil.

Corresponding author: sionaracarvalho@gmail.com
}

Suggested citation: de Caralho SMF, et al. Prevalence of major depression in patients with breast cancer. Journal of Human Growth and Development. 25(1): 68-74

Manuscript submitted Mar 08 2014, accepted for publication Jul 292014. 
psychosis. ${ }^{7}$ However, it is important to highlight that not every change in mood can be considered as depression. Often the patient only has mild emotional lability or mood changes.

Of all the mood complications linked to cancer, depression has been the most widely investigated, but despite many years of research, the prevalence of depression in cancer patients is still a matter of much debate. ${ }^{8}$

The prevalence of depression in patients with cancer has varied widely in different studies. An extensive review study, conducted by Spiegel, reported variations in rates between $4.5 \%$ to $50.9 \%$. Other studies have shown 'a variation of between $3 \%$ to $55 \%$ of cases of depression in breast cancer ${ }^{10-12}$. These studies generally encompass all depressive disorders and not just major depression. 5,13,14 A lack of standardization, especially with regards to methods of assessment, questionnaire scores to measure depression and diagnostic criteria contribute to the large discrepancy between the values. In general, the more specifically the term 'depression' is defined and evaluated, the lower the prevalence rates reported, including a meta-analysis published in 2011 in The Lancet, in which the authors identified an association between low prevalence of depression and high-quality studies published recently. ${ }^{8}$

Although much is talked of the association between breast cancer and depression, several studies have failed to show statistical significance between depression and cancer-related variables. Risk factors for depression appear to be more related to the patient rather than to the cancer itself or its treatment. ${ }^{6,12,15-21}$ The hypothesis tested in this study is the prevalence of major depression in patients with breast cancer is similar to the community samples of around 5\%. ${ }^{7,22-24}$. A patient's psychosocial factors, particularly their social and premorbid characteristics and inherent personality, are most often associated with depression in breast cancer.

Thus, the objective of this study was to determine the prevalence of major depression in women with breast cancer.

\section{METHODS}

A cross-sectional study of prevalence in Cariri Oncology Center, located in Barbalha - CE, in northeastern Brazil was conducted.

The total sample consisted of 51 women. The calculation for determining the size of this sample considered the prevalence of major depressive disorders as $5 \%$ (prevalence in adult women in the general population ${ }^{7.22-24}$ ) absolute precision of $6 \%$ and a significance level of $5 \%$.

Inclusion criteria were: patients had to be older than 18, diagnosed with breast cancer and were receiving anticancer treatment, and had signed an informed consent form.

Overall, 59 women were screened for the study, of whom 51 were enrolled in the study. Eight were excluded ( 3 because they were not undergoing treatment and 5 because they refused to participate in the research).

The occurrence of depression was detected through the Beck Depression Inventory (BDI). Statistical analysis was performed using the chisquare $\left(c^{2}\right)$. A questionnaire was also used with the following additional data: age, demographic and socio and economic data (marital status, ethnicity, education, family income), family history of depression, family history of breast cancer, time since diagnosis (in months), tumour staging, treatment performed, type of surgery (mastectomy or conservative surgery) and the occurrence of alopecia.

The BDI is probably the most used measure of self-assessment for depression both in research and in clinics ${ }^{25}$. Several findings corroborate its validity in clinical and non-clinical populations. It has been translated into several languages, including into Portuguese. ${ }^{26}$ It consists of a questionnaire containing 21 items, which include symptoms and attitudes, with an intensity ranging from 0 to 3 at a high gradation. A score of 0 represents the absence of symptoms or assessed attitude. A score of 3 equals the presence of symptoms or more serious attitudes. ${ }^{27,28}$ The 21 items assessed refer to sadness, pessimism, sense of failure, lack of satisfaction, guilt, sense of punishment, self-deprecation, self-accusation, suicidal ideas, crying spells, irritability, social withdrawal, indecisiveness, distortion of body image, work inhibition, sleep disturbance, fatigue, loss of appetite, weight loss, somatic preoccupation and decreased libido.

There are several proposed cut-off points to distinguish levels of depression using the BDI. The Center of Cognitive Therapy recommends the following cut-off points for samples of patients with affective disorder: $<10$ = no or minimal depression; $10-18=$ mild to moderate depression; $19-29=$ moderate to severe depression; $30-63=$ grave depression. ${ }^{29}$ Different guidelines recommend, for samples not diagnosed, that scores above 15 detect 'dysphoria' (defined by the authors as a 'non-specific negative affectivity'). They concluded that, because it refers to more severe cases, the term 'depression' should only be used for individuals with scores above $20 .{ }^{28,30}$ In updating these designations, dysphoria was classified in our study as subsyndromal depressive symptoms (SDS) and severe or grave depression were changed to major depression.

The standard cut-off points for this study were $<15=$ no depression, $16-20=$ subsyndromal depressive symptoms, $>20=$ major depression.

\section{RESULTS}

Among the 51 women with breast cancer, the prevalence of major depression was $5.9 \%$ (Table 1 ). Only three patients had a BDI score of $>20$. This prevalence rate was therefore similar to that found in the general female population.

Of the patients, $21.6 \%$ had subsyndromal depressive symptoms and $72.5 \%$ (Table 1 ) were classified, according to BDI, as having no change (score < 15). 
Table 1: Distribution of 51 women with breast cancer, classified according to the Beck Depression Inventory. Barbalha-CE, Brazil, in 2014

$\begin{array}{lcc}\text { BDI Score } & \text { N } & \text { \% } \\ \text { No alteration } & 37 & 72,5 \\ \text { SDS } & 11 & 21,6 \\ \text { Depression } & 3 & 5,9 \\ \text { Total } & 51 & 100\end{array}$

Abbreviations: BDI, Beck's Depression Inventory; SDS, Subsyndromal Depressive Symptoms.

Table 2 shows general data related to the 51 patients studied. An average age of $58.5 \pm$ 14.2 years old was verified, with values between 26 (minimum age) and 86 (maximum age), 70.6\% of them were between the ages of 40 and 69 years. Of those surveyed, $58.8 \%$ were married and $64.7 \%$ were white (ethnic categorization followed the classification of the Brazilian Institute of Geography and Statistics, which considers skin colour). With regards to education, $82.4 \%$ had not completed high school and only $9.8 \%$ had a college degree. With respect to family income (based on the Brazilian minimum wage which corresponds to US\$289.58 per month), 86.3\% had an income of up to US\$579.17 per month. A total of $9.8 \%$ patients had a family history of breast cancer and $13.7 \%$ had a family history of depression.

Table 2: Characteristics related to 51 women with breast cancer, distributed according to the classification of the Beck Depression Inventory (BDI), then $c^{2}$ test. Barbalha-CE, Brazil, in 2014

\begin{tabular}{|c|c|c|c|c|c|c|c|c|c|}
\hline \multirow[b]{2}{*}{ Variables } & \multirow[b]{2}{*}{ Total (\%) } & \multicolumn{2}{|c|}{ No alteration } & \multicolumn{2}{|c|}{ SDS } & \multicolumn{2}{|c|}{ Depression } & \multicolumn{2}{|c|}{$\chi^{2}$} \\
\hline & & $\mathbf{N}$ & $\%$ & $\mathbf{N}$ & $\%$ & $\mathbf{N}$ & $\%$ & $\chi^{2}$ & $\mathbf{P}$ \\
\hline \multicolumn{10}{|l|}{ Age (in years) } \\
\hline$<40$ & $5(9,8)$ & 3 & 8,1 & 1 & 9,1 & 1 & 33,3 & 2,918 & 0,232 \\
\hline 40 to 59 & $18(35,3)$ & 17 & 46,0 & 1 & 9,1 & 0 & - & & \\
\hline 60 to 69 & $18(35,3)$ & 12 & 32,4 & 4 & 36,4 & 2 & 66,7 & & \\
\hline$>70$ & $10(19,6)$ & 5 & 13,5 & 5 & 45,4 & 0 & - & & \\
\hline Total & $51(100)$ & 37 & 100 & 11 & 100 & 3 & 100 & & \\
\hline \multicolumn{10}{|l|}{ Marital Status } \\
\hline Married & $30(58,8)$ & 22 & 59,5 & 5 & 45,4 & 3 & 100 & 3,399 & 0,493 \\
\hline Widow & $11(21,6)$ & 7 & 18,9 & 4 & 36,4 & 0 & - & & \\
\hline Single & $8(15,7)$ & 6 & 16,2 & 2 & 18,2 & 0 & - & & \\
\hline Divorced & $2(3,9)$ & 2 & 5,4 & 0 & - & 0 & - & & \\
\hline \multicolumn{10}{|l|}{ Total } \\
\hline Ethnicity & $51(100)$ & 37 & 100 & 11 & 100 & 3 & 100 & & \\
\hline White & $33(64,7)$ & 26 & 70,3 & 5 & 45,4 & 2 & 66,7 & 4,363 & 0,628 \\
\hline Brown & $11(21,6)$ & 7 & 18,9 & 3 & 27,3 & 1 & 33,3 & & \\
\hline Black & $7(13,7)$ & 4 & 10,8 & 3 & 27,3 & 0 & - & & \\
\hline Total & $51(100)$ & 37 & 100 & 11 & 100 & 3 & 100 & & \\
\hline \multicolumn{10}{|l|}{ Education } \\
\hline$<$ High School & $42(82,4 \%)$ & 30 & 81,1 & 10 & 90,9 & 2 & 66,7 & 2,098 & 0,350 \\
\hline Completed High School & $4(7,8 \%)$ & 3 & 8,1 & 0 & - & 1 & 33,3 & & \\
\hline College Graduate & $5(9,8 \%)$ & 4 & 10,8 & 1 & 9,1 & 0 & - & & \\
\hline Total & $51(100 \%)$ & 37 & 100 & 11 & 100 & 3 & 100 & & \\
\hline \multicolumn{10}{|c|}{ Family Monthly Income (US\$) } \\
\hline$<289,58$ & $23(45,1 \%)$ & 18 & 48,7 & 5 & 45,5 & 0 & - & 2,098 & 0,911 \\
\hline$>289,58$ and $<579,17$ & $21(41,2 \%)$ & 13 & 35,1 & 5 & 45,5 & 3 & 100 & & \\
\hline$>579,17$ & $7(13,7 \%)$ & 6 & 16,2 & 1 & 9 & 0 & - & & \\
\hline Total & $51(100 \%)$ & 37 & 100 & 11 & 100 & 3 & 100 & & \\
\hline \multicolumn{10}{|c|}{ Family History of depression } \\
\hline No & 44 & 31 & 83,8 & 11 & 100 & 2 & 66,7 & 12,159 & 0,059 \\
\hline Yes & 7 & 6 & 16,2 & 0 & - & 1 & 33,3 & & \\
\hline Total & 51 & 37 & 100 & 11 & 100 & 3 & 100 & & \\
\hline \multicolumn{10}{|c|}{ Family History of Breast Cancer } \\
\hline No & 46 & 32 & 86,5 & 11 & 100 & 3 & 100 & 11,593 & 0,313 \\
\hline Yes & 5 & 5 & 13,5 & 0 & - & 0 & - & & \\
\hline Total & 51 & 37 & 100 & 11 & 100 & 3 & 100 & & \\
\hline
\end{tabular}

Abbreviations: SDS, Subsyndromal Depressive Symptoms; US\$, American Dollars. 
Table 3: Characteristics related to breast cancer and its treatment in 51 women, distributed according to the classification of the Beck Depression Inventory (BDI), then $\chi^{2}$ test. Barbalha-CE, Brazil, in 2014

\begin{tabular}{|c|c|c|c|c|c|c|c|c|c|}
\hline \multirow[b]{2}{*}{ Variables } & \multirow[b]{2}{*}{ Total (\%) } & \multicolumn{2}{|c|}{ No alteration } & \multicolumn{2}{|c|}{ SDS } & \multicolumn{2}{|c|}{ Depression } & \multicolumn{2}{|c|}{$\chi^{2}$} \\
\hline & & $\mathbf{N}$ & $\%$ & $\mathbf{N}$ & $\%$ & $\mathbf{N}$ & $\%$ & $\chi^{2}$ & $\boldsymbol{P}$ \\
\hline \multicolumn{10}{|c|}{ Time of diagnosis (in months) } \\
\hline$<12$ & $20(39,2)$ & 16 & 43,2 & 2 & 18,2 & 2 & 66,7 & 0,788 & 0,674 \\
\hline From 12 to 36 & $16(31,4)$ & 10 & 27,1 & 5 & 45,4 & 1 & 33,3 & & \\
\hline$>36$ & $15(29,4)$ & 11 & 29,7 & 4 & 36,4 & 0 & - & & \\
\hline Total & $51(100)$ & 37 & 100 & 11 & 100 & 3 & 100 & & \\
\hline \multicolumn{10}{|l|}{ Staging } \\
\hline IIA & $21(41,2)$ & 15 & 40,5 & 5 & 45,4 & 1 & 33,3 & 7,622 & 0,471 \\
\hline IIB & $8(15,7)$ & 7 & 19,0 & 1 & 9,1 & 0 & - & & \\
\hline IIIA & $7(13,7)$ & 4 & 10,8 & 2 & 18,2 & 1 & 33,3 & & \\
\hline IIIB & $14(27,4)$ & 11 & 29,7 & 2 & 18,2 & 1 & 33,3 & & \\
\hline IV & $1(2,0)$ & 0 & - & 1 & 9,1 & 0 & - & & \\
\hline Total & $51(100)$ & 37 & 100 & 11 & 100 & 3 & $100 *$ & & \\
\hline \multicolumn{10}{|c|}{ Type of treatment } \\
\hline $\mathrm{CIR}+\mathrm{QT}$ & $19(37,3)$ & 11 & 29,7 & 6 & 54,5 & 2 & 66,7 & 6,436 & 0,598 \\
\hline $\mathrm{CIR}+\mathrm{QT}+\mathrm{RT}$ & $18(35,3)$ & 14 & 37,9 & 4 & 36,4 & 0 & - & & \\
\hline $\mathrm{CIR}+\mathrm{QT}+\mathrm{RT}+\mathrm{HT}$ & $6(11,8)$ & 5 & 13,5 & 0 & - & 1 & 33,3 & & \\
\hline $\mathrm{CIR}+\mathrm{QT}+\mathrm{QT}$ & $4(7,8)$ & 4 & 10,8 & 0 & - & 0 & - & & \\
\hline QT only & $4(7,8)$ & 3 & 8,1 & 1 & 9,1 & 0 & - & & \\
\hline Total & $51(100)$ & 37 & 100 & 11 & 100 & 3 & 100 & & \\
\hline \multicolumn{10}{|l|}{ Type of surgery } \\
\hline Mastectomy & 30 & 22 & 59,5 & 6 & 54,5 & 2 & 66,7 & 0,368 & 0,985 \\
\hline Quadrantectomy & 17 & 12 & 32,4 & 4 & 36,4 & 1 & 33,3 & & \\
\hline No surgery & 4 & 3 & 8,1 & 1 & 9,1 & 0 & - & & \\
\hline Total & 51 & 37 & 100 & 11 & 100 & 3 & 100 & & \\
\hline \multicolumn{10}{|c|}{ Occurrence of alopecia } \\
\hline Yes & 38 & 28 & 75,7 & 7 & 63,6 & 3 & 100 & 3,116 & 0,211 \\
\hline No & 13 & 9 & 24,3 & 4 & 36,4 & 0 & - & & \\
\hline Total & 51 & 37 & 100 & 11 & 100 & 3 & 100 & & \\
\hline
\end{tabular}

Abbreviations: SDS, Subsyndromal Depressive Symptoms; CIR, Surgery; QT, Chemotherapy; RT, Radiotherapy; HT, Hormonetherapy. * The total was approximately 100.

Data related to breast cancer showed that $39.2 \%$ of patients had been diagnosed within the last 12 months, $70.6 \%$ were in a period of 36 months since their cancer diagnosis; $41.2 \%$ were at tumour stage IIA. Regarding the type of treatment, $92.1 \%$ had surgery, with $58.8 \%$ having undergone mastectomy; $37.3 \%$ of patients were treated with surgery and chemotherapy, and $35.3 \%$ had surgery combined with chemotherapy and radiotherapy. had Alopecia, resulting from the use of chemotherapy, affected $74.5 \%$

From the application of the chi-square test, there were no statistically significant differences $(p<0.05)$ in the classification of the BDI due to the variables tested, as shown in tables 2 and 3 . This occurred both in characteristics related to the patients themselves (age, marital status, ethnicity, education, family income, family history of depression, family history of breast cancer) and those related to breast cancer and its treatment (time since diagnosis, tumour stage, type of treatment, type of surgery and alopecia), indicating that the isolated context of the variables does not influence the event of depression. The only variable that showed a trend towards statistical significance $(p=0.059)$ was a family history of depression.

\section{DISCUSSION}

The prevalence of major depression among women with breast cancer found in this study was similar to rates reported in studies of women in the general population geral. $7,22-24$

Most of the patients studied showed no significant changes in mood, according to the classification from the scores of the Beck Depression Inventory (BDI). Although the diagnosis of breast cancer impacts on several areas of the patient's life, triggering mood swings, it was noticed that some women expressed subsyndromal depressive symptoms, but the vast majority did not have major depression (clinically significant depressive symptoms).

The diagnosis of cancer is an emotional overload; however, the onset of depression appears to be more related to the inherent characteristics of the patient (patient's personality and comorbidities pre-cancer) than to the characteristics related to cancer and its treatment. $6,12,15,16$

The variables studied in this article were selected from what the literature refers to as factors related to breast cancer and major depression. The results found support for the initial hypothesis, 
which admitted that the prevalence of major depression among women with breast cancer is similar to point prevalence found in community samples.

As in other studies, there was no statistically significant association of cancer-specific variables with depression, ${ }^{12,15-19,21}$ indicating that these variables alone did not have an influence on depression. The only variable with a trend toward statistical significance was a family history of depression ( $p=0.059$ ) and it is known that major depressive disorder is 1.5 to 3 times more common among first-degree biological relatives of people with this disorder than among the general population. ${ }^{7}$

Breast cancer is an unpleasant event that can bring traumatic experiences to the patient, such as fear of death, altered self-image, uncertainty as to treatment and prognosis. After receiving the diagnosis, many women face personal conflicts, some have difficulty in accepting the disease, seem afraid of suffering social discrimination or even discrimination within the family, in addition to facing feelings of mutilation resulting from complete or partial removal of the breast, the part of the body directly connected to the representation of her femininity. All these changes from the occurrence of cancer can be reflected as disturbances in mood, self-esteem and sexuality .

It is important to note, however, that all these changes caused by breast cancer in the context of the biopsychosocial woman do not necessarily lead to the onset of major depression - the patient may manifest milder affective disorders, adjustment reactions or subsyndromal depressive symptoms. It is assumed that functional, everyday stress and other disorders unrelated to cancer cause major influence on the patient's psychological function, due to factors inherent in the premorbid personality. ${ }^{16}$ Contextual variables, rather than risk factors directly related to cancer, appear to be predictive factors for the onset of depression in breast cancer patients ${ }^{12,15-17}$, among which stand out the structure of personality and problem-coping ability. ${ }^{6}$

The majority of our sample consisted of women older than 49 years old, white, married, of low education, low income, no family history of breast cancer and / or depression. With respect to breast cancer, most of them were within 36 months of diagnosis, had advanced staging, had surgery associated with other treatment modalities (chemotherapy, radiotherapy and / or hormone therapy), underwent total removal of the breast

\section{REFERENCES}

1. World Health Organization [internet homepage]. Genebra: The Organization; c2008. [cited 2014 May 07] Available from: http://www.who.int/en.

2. Instituto Nacional do Câncer [internet homepage]. Estimativa para o biênio 2014/ 2015: incidência de câncer no Brasil. Rio de Janeiro: INCA- Ministério da Saúde, c1996- (mastectomy) and also had alopecia due to chemotherapy.

After applying the chi-square test, it was found that age, marital status, and socio-economic status of patients (education and income) were not related to the depression event, nor to family history of breast cancer and depression.

It has been found that a shorter time since the diagnosis of cancer, the severity of the disease (late stages), the type of treatment (surgery, chemotherapy, radiation therapy and / or hormone therapy), as well as the type of surgery (removal or preservation of the breast) showed no correlation with major depression. This was also the case with respect to alopecia.

There is no consensus in the literature regarding the findings of association of variables related to cancer with depressive disorders. Some data suggest that the onset of mood disorders may vary according to the stage of cancer treatment, 20,31 staging ${ }^{32}$ or type of treatment ${ }^{33,34}$ while others found no cancer-specific influence. ${ }^{12,15,16}$

Breast cancer and depression are public health problems. When a community or population has a problem. the first step is to ask the question, what is the problem then to decide what works and decide on an intervention or a program ${ }^{35}$. Prevalence studies help in this first step it is important for public health decisions.

As can be seen in Table 1, it was considered that women with high scores (above 20) in BDI have major depression (clinically significant depressive symptoms). However, because it is a cross-sectional study, data regarding causality could not be determined.

The literature presents studies with very disparate prevalence rates of depression among breast cancer patients. ${ }^{5,8-10,13,14}$ However, these studies refer not only to depression, but include all types of depressive disorders. Major depression should not be confused with a simple sense of sadness, with transient changes in mood or mild depressive symptoms - to do so risks overestimating its prevalence; it is critical to assess patients carefully for the presence of depressive symptoms.

Thus, the more specifically the term depression is defined and evaluated, the lower the prevalence rates found in the literature, including the association between depression and the low prevalence of currently published high-quality scientific studies ${ }^{8}$.

In summary, the prevalence of major depression in women with breast cancer was $5.9 \%$.

2012. [cited 2014 May 07] Available from: http://www.inca.gov.br.

3. Carvalho SMF, Rolim Neto ML, Abreu LC, Celestino Junior FT. A panorama of cancer in Brazil. Neurobiologia. 2012; 75 (1-2): 206-8.

4. Hamaker ME, Jonker JM, Rooij SE, Gvos A, Smorenburg $\mathrm{CH}$, Munster BC. Frailty screening methods for predicting outcome of acomprehensive geriatric assessment in elderly patients with cancer: a systematic review. 
Lancet Oncol. 2012; 13(10): e437-44. doi: 10.1016/S1470-2045(12)70259-0.

5. Cangussu RO, Soares TBC, Barra AA, Nicolato R. Sintomas depressivos no câncer de mama: Inventário de Depressão de Beck - Short Form. J Bras Psiquiatr. 2010;59(2): 106-110.

6. Cantinelli FS, Camacho RS, Smaletz O, Gonsales $\mathrm{BK}$, Braguittoni E, Rennó Jr J. A oncopsiquiatria no câncer de mama - considerações a respeito de questões do feminino. Rev Psiquiatr Clin. 2006; 33(3): 124-133.

7. American Psychiatric Association. Diagnostic and Statistical Manual of Mental Disorder (DSM IV-TR) $4^{\mathrm{a}}$ ed. Washington, DC: American Psychiatric Association; 2000.

8. Mitchell AJ, Cham M, Bhatti H, Halton M, Grassi $\mathrm{L}$, Johansen $\mathrm{C}$, et al. Prevalence of depression, anxiety, and adjustment disorderin oncological, haematological, and palliative-care settings:a meta-analysis of 94 interview-based studies. Lancet Oncol. 2011; 12(2): 160-74. doi: 10.1016/S1470-2045 (11)70002-X.

9. Spiegel D. Cancer and depression. B J Psych. 1996; 168(30): 109-16.

10. Somerset W, Stout SC, Miller AH, Musselman D. Breast cancer and depression. Oncology. 2004; 18(8):1021-1034.

11. Fallowfield L, Hall A, Maguire GP, Baum M. Psychological outcomes of different treatment policies in women with early breast cancer outside a clinical trial. BMJ. 1990; 301 (6752):575-580.

12. Golden-Kreutz DM, Andersen BL. Depressive symptoms after breast cancer surgery: relationships with global, cancer-related, and life event stress. Psychooncology. 2004; 13(3): 211-20. Doi: 10.1002/pon.736.

13. Pasquini $M$, Biondi $M$. Depression in cancer patients: a critical review. Bio Med Central. 2007; 3 (2):1-9. doi: 10.1186/1745-0179-3-2.

14. Popoola AO, Adewuya AO. Prevalence and correlates of depressive disorders in out patients with breast cancer in Lagos, Nigeria. Psychooncology. 2012; 21(6): 675-9. Doi: 10.1002 /pon.1968

15. Ell K, Sanchez K, Vourlekis B, Lee PJ, DwightJohnson M, Lagomasino I, et al. Depression, correlates of depression, and receipt of depression care among low-income women with breast or gynocologic cancer. J Clin Oncol. 2005; 23(13): 3052-60. Doi: 10.1200/ JCO.2005.08.041.

16. Bardwell WA, Natarajan L, Dimsdale JE, Rock $\mathrm{CL}$, Mortimer JE, Hollenbach K, et al. Objective cancer-related variables are not associated with depressive symptoms in women treated for early-stage breast cancer. J Clin Oncol. 2006; 24(16):2420-7. Doi: 10.1200/JCO.2005.02. 0081

17. Wong-Kim EC, Bloom JR. Depression experience by young women newly diagnosed with breast cancer. Psychooncology. 2005; 14(7): 564-73. Doi: 10.1002/pon.873

18. Miller SL, Jone LE, Carney CP. Psychiatric sequelae following breast cancer chemotherapy: a pilot study using claims data. Psychosomatics. 2005; 46(6): 571-22. Doi: 10.1176/appi.psy.46.6.517.

19. Ganz PA, Desmond KA, Leedham B, Rowland $\mathrm{JH}$, Meyerowitz BE, Belin TR. Quality of life in long-term, disease-free survivors of breast cancer: a follow-up study. J Natl Cancer Inst. 2002; 94(1): 39-49. Page 73.
20. Burguess C, Cornelius V, Love S, Burguess C, Cornelius V, Love S, Graham J, Richards M, Ramirez A. Depression and anxiety in women with early breast cancer: five year observation a cohort study. BMJ. 2005; 330(7493): 702. Doi: $10.1136 / \mathrm{bmj} .38343 .670868$.D3.

21. Aukst-Margetic B, Jakovljevic M, Margetic B, Biscan M, Samija M. Religiosity, depression and pain in patients with breast cancer. Gen Hosp Psychiatry. 2005; 27(4): 250-55. Doi; 10.1016/ j.genhosppsych.2005.04.004

22. Massie MJ. Prevalence of depression in patients with cancer. J Natl Cancer Inst Monogr. 2004; (32): 57-71. Doi: 10.1093/jncimonographs/ Igh014

23. Esposito E, Wang JL, Adair CE, Williams JV, Dobson K, Schopflocher D, et al. Frequency and adequacy of depression treatment in a Canadian population sample. Can J Psychiatry. 2007; 52(12): 780-9.

24. Waraich P, Goldner EM, Somers JM, Hsu L. Prevalence and incidence studies of mood disorders: a systemactic review of the literature. Can J Psychiatry. 2004; 49(2): 12438.

25. Dunn G, Sham P, Hand D. Statistics and the nature depression. Psychol Med. 1993; 23(4): 871-89.

26. Gorenstein C, Andrade L. Validation of Portuguese version of the Beck depression inventory and the state-trait anxiety inventory in Brazilian subjects. Braz J Med and Biol Res. 1996; 29(4): 453-57.

27. Beck AT, Ward CH, Mendelson M, Mock J, Erbaugh G. An inventory for measuring depression. Arch Gen Psychiatry. 1961; 4: 53-63.

28. Gorenstein C, Andrade L. Inventário de Beck: propriedades psicométricas da versão em Português. Rev Psiq Clin. 1998; 25(5):245-50.

29. Beck AT, Steer RA, Garbin MG. Psychometric properties of the Beck depression inventoty: twenty-five years of evaluation. Clin Psycol Rev. 1988; 8(1): 77-100. Doi: 10.1016/0272-7358 (88)90050-5

30. Kendall PC, Hollon SD, Beck AT, Hammen CI, Ingram $\mathrm{RE}$. Issues and recommendations regarding use of the beck depression inventory. Cognitive Ther Research. 1987; 11(3): 289-99.

31. Schlegel RJ, Manning MA, Molix LA, Talley AE, Bettencourt BA. Predictors of depressive symptoms among breast cancer patients during the first year post diagnosis. Psychol Health. 2012; 27(3): 277-93. doi: 10.1080/088 70446.2011.559232.

32. Aapro M, Cull A. Depression in breast cancer patients: the need for treatment. Ann Oncol. 1999; 10: 627-36.

33. Leedham B, Ganz PA. Psychosocial concerns and quality of line in breast cancer survivors. Cancer Invest. 1999; 17(5): 342-48.

34. Schag CA, Ganz PA, Polinsky ML, Fred C, Hirji $\mathrm{K}$, Petersen L. Characteristics of women at risk for psychosocial distress in the year after breastcancer. J Clin Oncol. 1993; 11(4): 783-93.

35. Atrash HK, Carpentier R. The evolving role of public health in the delivery of health care. Rev Bras Crescimento Desenvolv Hum. 2012; 22(3): 396-99. 


\section{RESUMO:}

Introdução: o câncer de mama é uma das principais causas de morte entre as mulheres no Brasil e no mundo. O diagnóstico de neoplasia mamária geralmente representa uma sobrecarga emocional, podendo desencadear reações de ajustamento ou mesmo ser gatilho de quadros afetivos (principalmente depressão), ansiedade ou até mesmo psicoses. O Inventário de Depressão de Beck (IDB) é um dos instrumentos mais usados para avaliação de depressão, tanto em pesquisa quanto em clínica. A prevalência de depressão em pacientes com câncer tem variado bastante em diferentes trabalhos, de 3 a 55\%. A falta de padronização, especialmente no que diz respeito aos métodos de avaliação, escore/ponto de corte, tipo de entrevista e critérios para diagnóstico contribuem para a grande discrepância nos achados desses estudos. No geral, quanto mais especificamente o termo depressão é definido e avaliado, menores índices de prevalência são reportados. Vários trabalhos falharam em mostrar significância estatística entre depressão e variáveis relacionadas ao câncer, sugerindo que os fatores de risco para depressão parecem estar mais relacionados à própria paciente, como variáveis contextuais e fatores pré-mórbidos inerentes à sua personalidade, do que ao câncer em si ou ao seu tratamento. Objetivo: determinar a prevalência de depressão maior em mulheres com câncer de mama. Método: foi realizado um estudo transversal de prevalência em mulheres com câncer de mama. A amostra foi constituída por 51 pacientes que responderam o Inventário de Depressão de Beck (IDB). Considerou-se como presença de depressão os escores maiores do que 20. Foi aplicado também um questionário contendo dados complementares referentes às pacientes (idade, estado civil, etnia, escolaridade, renda familiar mensal, história familiar de depressão e de câncer de mama) e ao câncer (tempo de diagnóstico, estadiamento, tipo de tratamento, ocorrência de alopécia). Foi realizada análise descritiva e teste de associação (qui-quadrado). Resultados: a prevalência de depressão maior encontrada foi de 5,9\%, semelhante à observada na população feminina não portadora de câncer de mama. 21,6\% apresentaram sintomas depressivos subsindrômicos (escores do IDB de 16 a 20). A partir do teste de qui-quadrado, não foram observadas diferenças estatisticamente significativas $(p<0,05)$ na classificação do IDB em função das variáveis testadas (características referentes às pacientes e ao câncer em si), indicando que o contexto isolado das variáveis não exerce influência sobre o evento depressão. Conclusão: mulheres com câncer de mama apresentaram prevalência de depressão maior de 5,9\%.

Palavras-chave: câncer de mama, neoplasia de mama, prevalência, estudos transversais, depressão maior, transtorno de humor. 